Click www.researchjournal.co.in/online/subdetail.html to purchase.

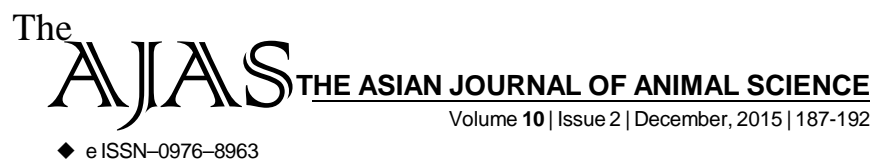

DOI : 10.15740/HAS/TAJAS/10.2/187-192 Visit us | www.researchjournal.co.in $\mathrm{S}$

RESEARCH ARTICLE.

\title{
Influence of stocking density on growth performance of vencobb broiler
}

S.K. GUPTA, K. BEHERA, S.A. LONE AND D. BEHERA

Author for Corresponding -

\section{S.K. GUPTA}

Department of Livestock

Production and Management,

ICAR-National Dairy Research

Institute, KARNAL (HARYANA)

INDIA

Email: sgshailesh786@gmail.com

See end of the article for

Coopted authors'

\begin{abstract}
The objective of the study was to evaluate the influence of stocking density on growth performance of vencobb commercial broiler reared upto 46 days under deep litter system. The birds were fed adlib with commercial broiler feed. Deep litter rearing arrangements were prepared 2 days prior to the arrival of chicks. Vaccination, housing, feeding and watering was done as per standard. A total of 120, day old chicks were divided in three equal groups (I, II and III) with 40 birds in each group. The birds were reared under stocking densities of 16 birds $/ \mathrm{m}^{2}$ (group I), 12 birds $/ \mathrm{m}^{2}$ (group II) and 8 birds $/ \mathrm{m}^{2}$ (group III). Feed consumption was significantly $(\mathrm{p}<0.01)$ higher under stocking densities of $12 \mathrm{birds} / \mathrm{m}^{2}$ and $8 \mathrm{birds} / \mathrm{m}^{2}$ as compared to stocking density of $16 \mathrm{birds} / \mathrm{m}^{2}$. Average live weight and carcass weight were significantly $(\mathrm{p}<0.01)$ higher under stocking density of $12 \mathrm{birds} / \mathrm{m}^{2}$. There was no significant difference in the feed conversion ratio (FCR) among all three groups. Dressing percentage was better with low stocking density of $12 \mathrm{birds} / \mathrm{m}^{2}(71.05 \pm 2.98)$ and $8 \mathrm{birds} / \mathrm{m}^{2}(72.29 \pm 1.04)$ as compared to high stocking density $\left(16 \mathrm{birds} / \mathrm{m}^{2}\right)$. In group I, feed consumption was positively correlated with live weight $(\mathrm{r}=0.87), \mathrm{FCR}(\mathrm{r}=0.67)$ and dressing percentage $(\mathrm{r}=0.90)$ and carcass weight $(\mathrm{r}=0.91)$. Live weight was positively correlated with $\mathrm{FCR}(\mathrm{r}=0.79)$, dressing percentage $(\mathrm{r}=0.90)$ and carcass weight $(\mathrm{r}=0.86)$. FCR was positively correlated with dressing percentage $(\mathrm{r}=0.90)$ and carcass weight $(\mathrm{r}=0.84)$. Dressing percentage was positively correlated with carcass weight $(\mathrm{r}=0.92)$. In group II, feed consumption was positively correlated $(\mathrm{p}<0.01)$ with live weight $(\mathrm{r}=0.97), \mathrm{FCR}(\mathrm{r}=0.98)$ and dressing percentage $(\mathrm{r}=0.96)$ and carcass weight $(\mathrm{r}=0.91)$. Live weight was positively correlated with FCR $(r=0.97)$, dressing percentage $(r=0.90)$ and carcass weight $(\mathrm{r}=0.93)$. FCR was positively correlated with dressing percentage $(\mathrm{r}=0.90)$ and carcass weight $(\mathrm{r}=0.92)$. Dressing percentage was positively correlated with carcass weight $(\mathrm{r}=0.98)$. In group III, feed consumption was positively correlated $(\mathrm{p}<0.01)$ with live weight $(\mathrm{r}=0.82), \mathrm{FCR}(\mathrm{r}=0.79)$ and dressing percentage $(\mathrm{r}=0.92)$ and carcass weight $(\mathrm{r}=0.91)$. Live weight was positively correlated with FCR $(r=0.81)$, dressing percentage $(r=0.79)$ and carcass weight $(\mathrm{r}=0.81)$. FCR was positively correlated with dressing percentage $(\mathrm{r}=0.83)$ and carcass weight $(\mathrm{r}=0.81)$. Dressing percentage was positively correlated with carcass weight $(\mathrm{r}=0.89)$.
\end{abstract}

KEY WORDS....... Stocking density, Feed intake, Broiler, Dressing percentage

HOW TO CITE THIS ARTICLE - Gupta, S.K., Behera, K., Lone, S.A. and Behera, D. (2015). Influence of stocking density on growth performance of vencobb broiler. Asian J. Animal Sci., 10(2): 187-192.

ARTICLE CHRONICLE - Received : 23.10.2015; Revised : 17.11.2015; Accepted : 23.11.2015 